\title{
Reinforcement Implementation of Six Tasks Through the Application of Edmodo-Based Blended Learning Model in Research Methodology for Physics Education Course
}

\author{
Ida Wahyuni ${ }^{1}$, Derlina ${ }^{2}$, Abd. Hakim ${ }^{3}$ \\ \{ida.wahyuni94@yahoo.co.id\} \\ Department of Physics Education, State University of Medan ${ }^{1,2,3}$
}

\begin{abstract}
T his study aims to improve the quality of the student learning process and student learning outcomes in Research Methodology for Physics Education course by reinforcement the implementation of six tasks. The study was designed with classroom action research methods. Students in blended learning are integrated between face-to-face lectures in class with online learning through Edmodo learning with the reinforcement of six tasks namely routine assignment, critical book report, critical journal report, mini research, project and engineering ideas will be directed to produce products in the form of feasible research proposals proceed to thesis guidance. The results obtained $71 \%$ of students 'thesis proposals in Research Methodology for Physics Education course score above 80 . Based on the results obtained it can be concluded that Reinforcement the implementation of six tasks can improve students' ability in preparing thesis proposals.
\end{abstract}

Keywords: Six Tasks, Edmodo-Based Blended Learning Model, Research Methodology for Physics Education

\section{Introduction}

The Indonesian National Qualification Framework (KKNI) is a competency classification qualification framework that can pair, equalize, and integrate between education and job training fields as well as work experience in the framework of providing recognition of work competencies in accordance with the work structure in various sectors. The Indonesian National Qualification Framework is a reference in curriculum and education quality assurance so as to produce graduates according to the IQF competency, students are better prepared to become responsive and adaptable graduates to the competition that occurs in the era of globalization, not only excel in academics, but also have the character as a stock to face job market. For this reason, UNIMED develops learning models that encourage student independence in learning. One of them requires each student to complete 6 assignments for each subject for each semester since the 2016/2017 Academic Year.

Six tasks required of students the first task is Routine Tasks are tasks performed on every meeting. The second task is Critical Book Report which examines the books based on the concept or theory learned in a course to determine the critical position that does study. The third task is the Critical Journal Report. Is reviewing all components of a research report or journal critically. With the main goal, find the advantages and disadvantages of a research or 
journal and display relevant suggestions to maintain strength and overcome the weaknesses of the research or journal. The fourth task is Engineering Ideas, in this task, the lecturer and students discuss and determine the scope of ideas that can be engineered. The fifth task is Mini Research. This task is done by the way students and lecturers discuss and determine relevant research topics. The sixth task of students must be able to make Project that produces a model or product that has ethical, aesthetic, social, cultural, and economic values.

The course in research methodology for physics education is specifically designed for undergraduate students in the fifth semester to aim at equipping students to have the knowledge and experience in preparing a thesis in physic education proposals that are in accordance with the rules of scientific proposal preparation. In its implementation, students learn various methods of educational research, techniques of learning observation to identify the problems of learning physics at school so that they are expected to develop their ideas into thesis themes.

After completing this course, students are expected to be able to understand; (a) scientific philosophy, nature and method; (b) how to conduct research; (c) choosing a problem; (d) preliminary study; (e) formulating problems, basic assumptions, and hypotheses; (f) population, sample, and sampling method, $(\mathrm{g})$ determine and compile instruments and their analysis; (h) how to analyze data; and (i) making and compiling a thesis proposal on physical education at school.

The implementation of the physics education research methodology course was carried out with a cooperative learning model with student activities in groups discussing learning all lecture materials, composing papers, making power points and presenting them to other groups. This activity takes place from the beginning to the end of the lecture. In the KKNI curriculum, the grades obtained by students in this activity are categorized as routine tasks. For other assignments, CBR, CJR, MR, P and RI are assigned to students and collected at the agreed time. Very minimal guidance is given to students in carrying out all these tasks. The learning process can obtain good learning outcomes if the contents and procedures of learning are organized into meaningful sequences (Kabba, 2009). For this purpose, the procedures for implementing the six tasks in the IQF need to be carefully monitored and optimized, not just giving assignments without being properly feedbacked.

Besides that, the ideas and ideas of students cannot develop because some are identified as copying other people's thesis proposals in the form of a thesis. The introduction of various research methods in the learning process and observations to schools to identify the problems of physics learning, it turns out that it has not had a positive impact on the ability of students in preparing feasible proposals, then proceed to thesis guidance. The main problem lies in the ability of students to study various aspects related to research, such as studies of curriculum, learning strategies, articles and scientific writing is lacking so that the courage to independently prepare research designs most students do not appear. Indeed, the ability of students in preparing proposals can be optimized by strengthening the implementation of 6 tasks.

On the other hand, the presence of e-learning provides new innovations in the world of education with the widespread use of electronic communication media. (Miarso, 2015). The use of e-learning as a technology needs to be done in order to carry out effective learning and improve student learning outcomes. Seeing the needs of students and the demands of the times, a good learning strategy is to combine face-to-face learning in class and E-learning (Galang, et al, 2016). The choice of using a blended learning model is felt appropriate in the physics education methodology course. Blended learning does not mean replacing face-to-face learning activities in the classroom but strengthening the learning model (Fatwa, 2016). 
Edmodo learning is a form of e-learning learning, e-learning is defined as a form of information technology that is applied in the field of education in the form of virtual schools in either an independent or networked form (Purbo, 2001) and a school environment-based social network (Epinur, 2013). Edmodo is designed to create interaction between lecturers and students which emphasizes fast communication, polling, assignment, sharing ideas, and many more things. As a lecturer, Edmodo provides features for sharing files, links, tasks, values and warnings directly to students (Solihin, et al, 2015). In addition, Edmodo can also be accessed by parents.

\section{Method}

We strongly encourage authors to use this document for the preparation of the cameraready. Please follow the instructions closely in order to make the volume look as uniform as possible (Moore and Lopes, 1999).

The Research subjects involved in this action research were Grade A Physics Education Study Program 2016 students who took the Educational Research Methodology course on the odd semester of the 2018/2019 academic year in July-December 2018. The study was designed with classroom action research methods to overcome problems student learning, because of the difficulty in compiling thesis proposals by applying a blended learning model (combining face-to-face cooperative learning models in classes with Edmodo-based online learning) applying 6 tasks namely routine assignments, Critical Book Report, Critical Journal Review, Mini Research, Idea Engineering and Project. Blended learning based on 6 tasks.

Classroom action research carried out in each cycle includes four stages: (1) planning, (2) acting, (3) observing, (4) reflecting. The activity process which includes four stages is referred to as one cycle (Susilo, 2009).

The steps taken in each cycle in more detail can be explained as follows. The steps taken in planning include:

1. Revise the lecture contract.

2. Designing a worksheet for its 6 assignments and assessment rubrics

3. Arranging instruments for evaluating student proposals to judge it feasible or not to continue as a thesis proposal.

In the implementation phase, learning is done with a model of blended learning based on 6 tasks. The tasks done by students in study groups differed at each meeting adjusted to 6 types of tasks carried out systematically ranging from routine assignments, CBR, CJR, Mini Research, Project and Idea Engineering.

Reflection is carried out based on the results of observations and data analysis of learning outcomes achieved by students in each assignment given, as well as describing the progress achieved, the obstacles faced and efforts to overcome them. The results of further reflection will be used as a basis for determining the improvement of actions in the next cycle and task.

\section{Result}

The data obtained from the study consisted of learning outcomes data obtained from 3 task product assessments consisting of RT values, CBR values and values CJR. The increase in RT, values CBR and CJR from cycle I to cycle II is presented in Table 1. 
Table 1. Description of Improved Student Learning

\begin{tabular}{llllll}
\hline No. & Average & First Cycle & Second Cycle & N-gain $(\%)$ & Category \\
\hline 1. & RT & 63 & 75 & 32,4 & Medium \\
2. & CBR & 53 & 72 & 40,4 & Medium \\
3. & CJR & 56 & 76 & 45,5 & Medium \\
\hline
\end{tabular}

Observation results on the process of implementing 6 tasks in terms of student learning activities.

The activeness of students in cycles I and II during the learning process is presented in Table 2.

Table 2. Description of Improved Student Learning

\begin{tabular}{lllll}
\hline Students Activity & \multicolumn{3}{l}{ Percentage Activity } & \\
\cline { 2 - 5 } & 1st Cycle & Category & 2nd Cycle & Category \\
\hline Reading & 76 & Active & 84 & Very Active \\
Noting & 68 & Less Active & 72 & Active \\
Discussion & 70 & Active & 84 & Very Active \\
Asking / answers questions & 62 & Less Active & 76 & Active \\
Giving ideas & 60 & Less Active & 76 & Active \\
Irrelevant activity & 70 & Active & 48 & Less Active \\
Average & 68 & Less Active & 73 & Active \\
\hline
\end{tabular}

To find out the student's response to the implementation of learning in the Research Methodology Education subject by applying a blended learning model using Edmodo to students is given a questionnaire. Student response data is presented in Table 3.

Table 3. Description of Improved Student Learning

\begin{tabular}{|c|c|c|c|}
\hline \multirow[t]{2}{*}{ No. } & \multirow[t]{2}{*}{ Observed aspect } & \multicolumn{2}{|c|}{ Answer } \\
\hline & & SS & $\mathrm{S}$ \\
\hline 1. & Research methodology courses become more interesting & 19 & 7 \\
\hline 2. & Develop hard work and independence & 17 & 8 \\
\hline 3. & Develop thinking skills to find the latest references & 20 & 5 \\
\hline 4. & Develop students' insight and curiosity & 21 & 4 \\
\hline 5. & Increase student activity & 20 & 5 \\
\hline 6. & $\begin{array}{l}\text { A real experience critiquing books articles simplify the } \\
\text { preparation of proposals Thesis }\end{array}$ & 25 & 0 \\
\hline
\end{tabular}

Blended learning, combining face-to-face learning with learning online using Edmodo. In this study face-to-face learning is done with cooperative learning models. In the introductory activity the lecturer conveyed all the learning objectives to be achieved and motivated students, followed by presenting information, group collaboration and presentations. In learning Online lecturers use Edmodo facilities such as; quizzes, assignments, and chat. Lecturers Upload assignments a week before face to face in class. The supporting factors are learning with Edmodo, namely the availability of supporting facilities on campus namely projectors, laptops, and wireless internet networks (Wi-Fi). Besides that, there is an application that can be downloaded with a smartphone, so that it can be accessed anywhere 
and anywhere using a smartphone. This learning can maximize learning time can be done anywhere and anytime and is not boring. This learning is also able to save costs because there is no need for hard copy of material, and teach students to study independently.

The factor that inhibits blended learning -based Edmodo is that there are some students who do not have a data plan to access and internet networks that are again disrupted.

There are several suggestions from students who experience learning to use blended learning, among others: learning needs to be carefully prepared so that the impact of learning is effective, improving internet connection because e-learning will be implemented if it is supported by a good internet connection, improving interaction between lecturers and students in e-learning, so we need a place in e-learning that is able to become a discussion forum for students and lecturers.

Some obstacles experienced by researchers in conducting blended learning, among others: Lecturers still do not fully understand how to use e-learning in learning, there is no e-learning readiness so there is no discussion place for students and lecturers, internet connection is not smooth so the implementation of learning tends to require a relatively long time. The same thing was discovered by Islamiyah and Lilis (2016).

The implementation of the 6 assignments in this lecture was carried out in an integrated manner, namely students seeking information and learning about lecture material as routine tasks by conducting CBR and CJR. To understand the meaning of each component in the thesis proposal chapter 1, chapters 2 and 3, students do CBR and CJR. Furthermore, so that students can write a thesis proposal, students are given the task of MR, RI and Project. On MR students are trained to make backgrounds, problem formulation, hypothesis formulation, research title, theoretical framework handout, and research methods through CBR and CJR. Students carry out several activities, namely: reviewing books, downloading national-scale journals and international, describing the background of the available books and journals, describing the problem formulation based on the background, describing the hypothesis formulation, describing the research title, describing the hand out of the theoretical framework and describing the research method.

Obstacles contained in writing a thesis proposal According to JJ. Siang (2009) can come from internal and external factors. Internal factors include lack of motivation in students and low academic ability, external factors that are difficult to find ideas / problems that will be used as a thesis title, difficulty in searching literature, and problems with supervisors during consultation. Motivation is a power or strength that arises in itself to provide readiness so that the goals set have been achieved by Riduwan (2010).

The results of reflection on learning activities have identified several problems that show that the ability of students to understand the basic concepts of research and the ability to compile a thesis proposal is still low, various problems are found namely; students do not understand the basic concepts of research, do not understand the meaning and definition of each component of the thesis proposal, the thesis title is mostly not the result of identification of learning problems in school but rather reading the previous thesis, the literature review used is not factual because it does not originate from the latest references, and minimal references that are sourced from the research journal.

The enthusiasm of the students working on 6 tasks in order to be able to write a thesis proposal that is suitable for use as a final project is very high. But at the beginning of the activities in the first cycle, most of them were still unable to provide ideas or ideas when discussing through class discussions. After reflection with observers, information was obtained that most students were busy with reading and compiling the results of their 
individual articles, and had not been given more opportunities to share information on the results of their studies.

Reading Literature tends to be disliked by students so that it becomes an obstacle in preparing proposals. With the task of CJR and CBR requiring students to criticize and take the essence of reading material inevitably it forces students to read books and journals that are relevant to the topic they choose. It is strange that students can write proposals well without ever reading journals and references related to the journal. For example, how can students be able to write conceptual frameworks well without understanding the meaning of the conceptual framework and without ever reading the conceptual framework created by other authors. Reading the literature to improve the ability of students to get the latest research problems is not just copying the problems of their senior high school thesis. Besides that, with the task, CJR students get a comparison of the thoughts of several writers, reviewing thoughts by reading their works and entering into the proposals that are being made are important requirements in writing a thesis proposal.

Based on the observations of activities CJR, most students have meaningful experience in choosing journals that are relevant to the topic of the problem, factual and sourced from journals that are ISSN online or printed. This condition is according to Parmin (2012) because students if given the opportunity and the trust to trace learning resources in the form of journals or articles are able to get the right article according to their field of study. Provision of motivation that stimulates curiosity to be able to choose thesis problems that are factual is proven to be able to trigger the activity of reading, recording, and compiling the results of the study in accordance with the established systematics.

The task of MR, RI at first was very difficult for students difficult to describe, explain the ideas in their minds in writing in sequence. As well as sometimes when there is a new idea or a more interesting one than before, it will try to think of a new topic before the topic is finished. To overcome this difficulty, students are guided to choose only one focus of the problem / problem and complete it to completion, trying to formulate the problem in the topic, outlining the creative ideas that will be conveyed and determining and making goals and benefits.

Idea engineering is a vehicle for students to practice writing creative ideas as an intellectual response to the actual problems faced by society. Engineering ideas to make students think creatively and objectively because students are given the opportunity to give creative ideas that offer solutions to problems that develop in society. subjective, writings are supported by reliable data and / or information, and are genuine (not plagiarized) and avoid duplication. Engineering ideas develop the ability to think logically and systematically because each step of writing is designed systematically and in harmony.

\section{Conclusions}

There is an increase in student learning outcomes and activities through the application of a learning model blended by strengthening six assignments in Research Methodology for Physics Education course.

Acknowledgements. Thank you very much to the Chancellor, the Dean of FMIPA, the Head of the Research Institute and all the facilitating parties so that this research can be carried out. 


\section{References}

[1]Epinur, Yusnidar, dan Lestrai Eka Putri, "Pengembangan Media Pembelajaran Kimia Pada Materi Sistem Periodik Unsur Menggunakan Edmodo Berbasis Social Network Untuk Siswa Kelas X IPA 1 Sma N 11 Kota Jambi”, J. Ind. Soc. Integ. Chem., Volume 5, Nomor 2(2013) h. 24.

[2]Fatwa, Alyan, Djuniadi.2016 Strategi Blended Learning Untuk Meningkatkan Hasil Belajar Pokok Bahasan Persamaan Dan Fungsi Kuadrat. Jurnal SENIT. http://ejournal.poltektegal.ac.id/index.php/prosiding/article/view/356.

[3]Galang, Akbar, M, Wahyuni Suryaningtiyas, Febriana Kristanti. 2016. Pengaruh Model Pembelajaran Blended Learning terhadap Hasil Belajar Matematika Kelas VII SMP 38 Surabaya, e.Jurnal FKIP UM Surabaya,Vol 3 No.2.

[4]Hake \& Richard, R. 2002. Relationship of Individual Student Normalized Learning Gains in Mechanics with Gender, High-School Physics, and Pretest Scores on Mathematics and Spatial Visualization.

[5]Kabba E. Colley. 2009.Based Science Instruction: Teaching Science for Understanding. Journal of Research in Science Teaching. Vol. 39, No. 5, pp. (410-422).

[6]Parmin. 2012. Penerapan Critical Review Artikel Pembelajaran IPA untuk Meningkatkan Kemampuan Mahasiswa dalam Menyusun Proposal Skiripsi. Jurnal Pendidikan IPA Indonesia. Vol.1(2) (2012) 183-191.

[7]Purbo, O.W. 2001. Teknologi E-Learning. PT Elex Media Komputind: Jakarta.

[8]Susilo, H., Husnul C, dan Yuyun D. 2009. Penelitian Tindakan Kelas. Surabaya: Bayumedia Publishing.

[9]Miarso, Yusufhadi. 2015. Menyemai Benih Teknologi Pendidikan, edisi kedua. Jakarta: Prenadamedia Group.

[10]Solihin Riyandi Putra, dkk, Pengembangan Media Pembelajaran Edmodo dengan Video Tutorial dada Instalasi Jaringan Lan Peer to Peer Jurusan TKJ di SMKN I Bunut," J. Ind. Soc. Integ. Chem., Vol 5, No 2, (2015), ejurnal. bunghatta.ac.id/index.php?journal=JFKIP\&page=article\&o,h. 2.

[11]Islamiyah, Mufidatul dan Lilis Widayanti. 2016. Efektifitas Pemanfaatan E-Learning Berbasis Website Terhadap Hasil Belajar Mahasiswa STMIK Asia Malang Pada Mata Kuliah Fisika Dasar. Jurnal Ilmiah Teknologi dan Informasia ASIA (JITIKA) Vol.10, No.1, Februari 2016. 